\title{
CHARACTERISTICS OF RESPIRATORY FUNCTIONS AND PHYSICAL CAPACITY IN CHILDREN LIVING UNDER CONDITIONS OF LOW-DEGREE AIR POLLUTION
}

\author{
Turnovska T. $^{1}$, Bl. Marinov $^{2}$, St. Mandadjieva ${ }^{2}$ \\ ${ }^{1}$ Department of Hygiene and Ecomedicine, ${ }^{2}$ Department of Pathological Physiology, \\ Medical University of Plovdiv
}

Reviewed by: Assoc. Prof. M. Peneva

\begin{abstract}
Introduction: Air pollution has considerably decreased in many of the urbanized territories in Europe in the last 10 to 15 years, as compared to its levels in the middle of the previous century. This is the reason why nowadays the indicators morbidity and mortality, widely used at the time to assess health, are not effective enough. Under the contemporary conditions of lower concentrations of air pollutants, much more precise methods are required to characterize the consequences of air pollution for the health. The aim of the present study was to analyze respiratory functions and physical capacity in children living under conditions of low degree air pollution. Methods: In 2004 we carried out a complete functional study of respiration and a cardiopulmonary exercise testing among 93 children ( 50 boys/43 girls) aged $13.36 \pm 0.53(\mathrm{X} \pm \mathrm{SD})$ years. According to data of the Regional Inspectorate of Environment and Water Resources, the latter live at air pollutant levels which are under or a little above the maximum admissible concentrations. Results: The mean annual concentrations of controlled pollutants were: $(\mathrm{X} \pm \mathrm{SE}): \mathrm{TSPM}\left(\mathrm{mg} / \mathrm{m}^{3}\right)-\mathbf{0 . 1 3} \pm \mathbf{0 . 0 3 5}, \mathrm{SO}_{2}\left(\mathrm{Mg} / \mathrm{m}^{3}\right)-29.70 \pm 7.757, \mathrm{NO}_{2}\left(\mathrm{Mg} / \mathrm{m}^{3}\right)-$ $10.76 \pm 0.791, \mathrm{H}_{2} \mathrm{~S}\left(\mathrm{Mg} / \mathrm{m}^{3}\right)-0.05 \pm 0.020, \mathrm{~Pb}\left(\mathrm{Mg} / \mathrm{m}^{3}\right)-0.06 \pm 0.009, \mathrm{NH}_{3}\left(\mathrm{mg} / \mathrm{m}^{3}\right)-0.02 \pm 0.010$. Results: No deviations were observed in the mean values of the functional indices analyzed, which were over 40 in number, with regard to the referent levels for the respective age and $\operatorname{sex}(\mathrm{X} \pm \mathrm{SD}): \mathrm{VC}-3.50 \pm 0.62 \mathrm{~L}, \mathrm{FVC}-3.43 \pm 0.63 \mathrm{~L}$, FEV1 - 3.14 $\pm 0.56 \mathrm{~L}$, Tiffneau $-89.79 \pm 5.18 \%$, etc. The individual assessment showed lower values for some indices (predominantly in the boys) - TLCpred under 90\% (81.6489.8\%), MEF50pred under $70 \%$ (58.1465.6\%), $\mathrm{MHF}_{2} 5$ pred under 60\% (34.7453.4), TLCOpred under 80\% (62.6479.9), etc. Conclusions: No pathologic changes were observed in the external breathing and physical capacity of the majority of the children studied, although in the more susceptible ones low degree air pollution caused reduction in some indices. The study of external breathing and physical capacity are adequate methods for health assessment of the influence of low degree pollution.
\end{abstract}

Key words: air pollution, pulmonary functions, physical capacity, treadmill exercise test

The transition to market economy in Bulgaria was characterized by a significant drop in industrial production, particularly of the big state enterprises, a considerable portion of which were major sources of air pollutants in the course of decades. This led to an improvement in the ecological situation after 1989 (1). The levels of concentrations of the main controlled pollutants in the most polluted regions in the country were significantly reduced $(2,3,9,11)$. A similar situation, although not so markedly expressed, was described in other countries in Central and Eastern Europe as well $(6,10)$. At the same time, reports were published, according to which a number of air pollutants (dust, sulfur dioxide, nitrogen oxides, ozone, ammonia, etc.) with concentrations approximately at or below the top-admissible levels, such as the ones recorded in Bulgaria after 1989, have a harmful effect on the health $(11,5)$. Careful examination of the problem of the effects on the health of low-level atmo- spheric pollution is extremely important because it is directly related to the substantiation of the boundary levels of air pollutants in the urban environment. One of the most precise indicators for the evaluation of health effects from the impact of air pollution is the level of respiratory functions (12); the best approach to determine the pre-pathological changes in the cardiopulmonal system such as the ones that can be expected in the presence of concentrations below or near the admissible boundary, is the analysis of its functions in the case of the physical loading of the organism (4); one of the most sensitive periods in human development with regard to environmental factors is early puberty $(13,14)$. For that reason, we set as a goal to analyze the respiratory functions and physical capacity in adolescents born and having lived under conditions of low-degree air pollution. 
One of the most industrialized and highly polluted regions in Bulgaria was the town of Dimitrovgrad. After 1989 the production of phosphorus fertilizers, phosphorus and sulfuric acids, sodium silicofluoride, dimethyl sulfate, phenylamine, heating energy, asbestos-cement products, etc. was fully discontinued and the volume of output of the other productions in Dimitrovgrad was greatly reduced. This led to an abrupt decrease in the air-pollutant levels.

\section{MATERIALS AND METHODS}

The primary information about air pollution was collected from the three permanent stations with manual sample-taking of the Regional Inspection of Environment and Waters and the Sanitation and Epidemiology Inspection in the city. The results were calculated as mean year levels for the town in total.

In 2004 we carried out a functional study with assessment of spirometric and cardiopulmonary exercise parameters in 93 clinically healthy children ( 50 boys $/ 43$ girls) aged $13.36 \pm 0.53(\mathrm{X} \pm \mathrm{SD})$ years from the town of Dimitrovgrad living under or a little above the maximum admissible concentrations. The study was conducted in testing laboratory of Medical University of Plovdiv. Complete anthropometric measurements were performed before the actual test procedures. Pulmonary function testing was carried out with a diagnostic system Masterscreen Diffusion $^{\mathrm{TM}}$ (E. Jaeger, Wuerzburg, Germany) in a seated position with a nose clip in the following order: 1. Slow spirometry; 2. Measurement of diffusion capacity; 3. Forced expiration; 4. Maximal inspiratory and expiratory pressures. Predicted values were calculated automatically according to the reference equations of European Respiratory Society (ERS). Diffusing capacity (transfer factor - TL,co) was calculated as mean of two Single-Breath measurements. Tl,co values are given unadjusted for hemoglobin.

To elaborate on the possible differences in the reserves of the cardio-pulmonary system, the children performed an incremental treadmill test. It was carried out on a motor driven, electronically controlled treadmill (TrackMaster ${ }^{\mathrm{TM}}$, JAS Fitness Systems, Pensacola, FL, USA).

Throughout the test gas exchange variables were determined with an on-line computerized system $\mathrm{CardiO}^{\mathrm{TM}}$. Subjects breathed through a mouthpiece and a pneumotachometer was used for recording of tidal volume (Vt; mL.min-1, BTPS) and minute ventilation (VE; L.min-1, BTPS). Data were averaged every $30 \mathrm{sec}$. and used to calculate oxygen uptake $\left(\mathrm{VO}_{2} ; \mathrm{mL} . \mathrm{min}-1\right.$, STPD), carbon dioxide output $\left(\mathrm{VCO}_{2} ; \mathrm{mL} . \mathrm{min}-1\right.$, STPD) and respiratory exchange ratio (RER). Heart rate was monitored electrocardiographically (Hellige, Germany) and the oxygen saturation was traced with pulseoxymeter Pulseox DP-8 (Minolta, Japan). All analyses were performed using the Statistical Package in SPSS 16.0.1. for Windows.

\section{RESULTS AND DISCUSSIONS}

The mean year levels of pollutants by comparison with the corresponding limits are presented in a fig. 1.

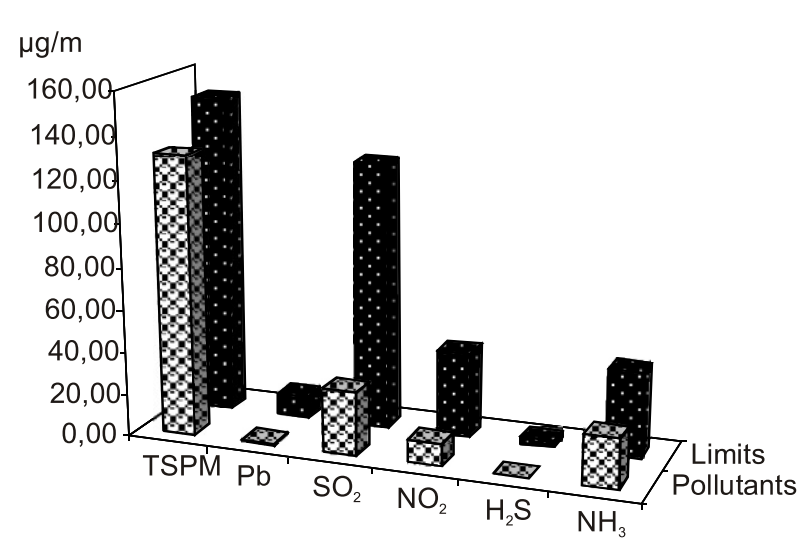

Fig. 1 Mean year levels of air pollution in Dimitrovgrad during 2004

The results have shown that the mean year concentrations of all pollutants are below the Bulgarian limits.

This means that we should not expect a harmful effect on the health of the exposed population, in this particular case of the studied students. In table 2 the results from the study of external breathing are presented as a percentage of the expected value.

Table 1.

\begin{tabular}{||c|c|c||}
\hline \multicolumn{3}{|c||}{ Respiratory Indices } \\
\hline Indices & Boys (X \pm SD) & Girls (X \pm SD) \\
\hline Age (y) & $13.3 \pm 0.5$ & $13.3 \pm 0.6$ \\
\hline Height (cm) & $163.1 \pm 8.6$ & $158.1 \pm 7.0$ \\
\hline Weight (kg) & $54.1 \pm 15.1$ & $49.3 \pm 7.5$ \\
\hline VC\%pred & $97.6 \pm 11.0$ & $104.4 \pm 12.9$ \\
\hline IC\%pred & $92.5 \pm 13.6$ & $98.5 \pm 19.6$ \\
\hline FVC\%pred & $96.5 \pm 11.2$ & $103.6 \pm 14.1$ \\
\hline FEV1\%pred & $104.4 \pm 12.2$ & $113.8 \pm 13.9$ \\
\hline Tiffneau (\%) & $88.4 \pm 5.6$ & $91.3 \pm 4.2$ \\
\hline MEF50\%pred & $100.9 \pm 20.7$ & $108.4 \pm 19.9$ \\
\hline MEF\%25pred & $96.3 \pm 30.1$ & $107.4 \pm 27.9$ \\
\hline TLCO\%pred & $92.3 \pm 12.5$ & $85.8 \pm 12.4$ \\
\hline TLC\%pred & $98.8 \pm 9.0$ & $103.2 \pm 9.5$ \\
\hline FRC\%pred & $116.0 \pm 27.1$ & $110.3 \pm 26.7$ \\
\hline VCin\%pred & $95.0 \pm 10.7$ & $102.3 \pm 13.3$ \\
\hline \hline
\end{tabular}

The presented data reveal that the average levels of all indicators correspond to the referential values, both for boys 
and girls. Furthermore, the levels of the main pulmonary indicators - vital capacity (VC\%pred) and forced expiratory volume in one second (FEV1\%pred) are close and over 100 percent - the median of the reference values. Special attention has to be paid to the maximal expiratory flow for $50 \%$ of the forced vital capacity (MEF50\%pred) because it has shown high sensitivity to airflow obstruction, but it is over $100 \%$ in this case. Another very important index is diffusion capacity (TLCO\%pred), which is used as a means of choice when studying the respiratory functions in harmful productions and highly polluted regions (8). As it can be seen, this indicator also is over $80 \%$ for both sexes. These results, in our opinion, mean that the submitted average annual concentrations of the studied pollutants have not led to negative changes in the external breathing of the studied contingent.

From the individual analysis of the results, however, some deviations from the referential values were found (table 2).

Table 2.

\begin{tabular}{||c|c|c||}
\hline \multicolumn{3}{|c||}{ Individual assessment } \\
\hline Indices & Boys (\% of all) & Girls (\% of all) \\
\hline $\begin{array}{c}\text { MEF50\%pred } \\
\text { (under 70\%) }\end{array}$ & 6.12 & 2.33 \\
\hline $\begin{array}{c}\text { MHF25\%pred } \\
\text { (under 60\%) }\end{array}$ & 6.12 & 2.33 \\
\hline $\begin{array}{c}\text { TLCO\%pred } \\
\text { (under 80\%) }\end{array}$ & 8.16 & 27.91 \\
\hline $\begin{array}{c}\text { TLC\%pred } \\
\text { (under 90\%) }\end{array}$ & 20.41 & 11.62 \\
\hline \hline
\end{tabular}

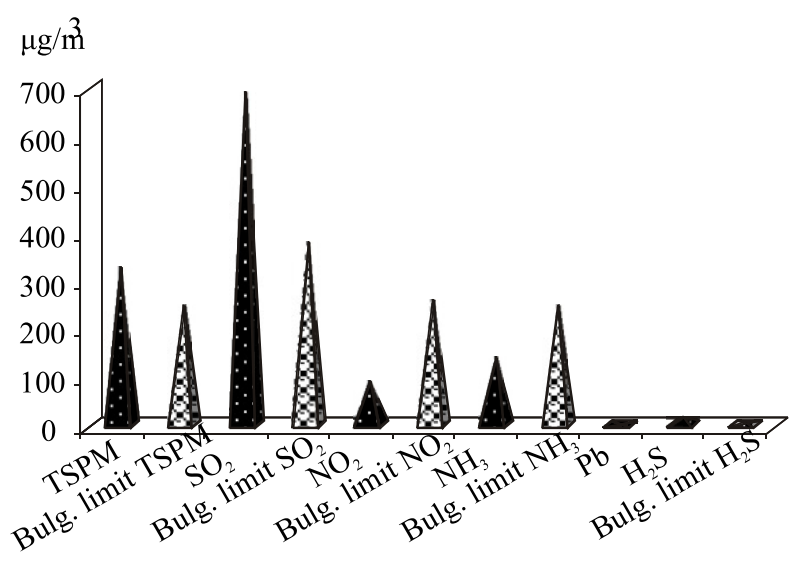

Fig. 2 Maximal concentrations of air pollutants during 2004

The analysis of the information from the survey forms submitted by these children showed that their lower results may be cause-related to passive smoking, to a bout of the flu in the 12 months prior to the study, including consequent complications - bronchitis or bronchial pneumonia; 2 children were diagnosed with "Bronchitis asthmatika". In addition, we should not overlook the impact of the high maximum single concentrations of the controlled pollutants either (figure 2), which are probably due to lack of rhythm in production during the period of economic crisis.

Especially significant are the data on sulfur dioxide which show it is almost twice the amount of the permissible level. Taking into consideration the fact that it is one of the major factors which is generally related to the decreased level of MEF50\%, we can assume that it contributes to this negative result. Moreover, we should also add its combined action with nitrogen oxide and hydrogen sulfide.

No reliable data were found on an impact from low-degree atmospheric pollution on the restriction of respiratory functions (average annual concentration of total suspended dust $-0.13 \mathrm{mg} / \mathrm{m}^{3}$ and sulfur dioxide $-40.84 \mathrm{mg} / \mathrm{m}^{3}$ ) in adolescents.

In order to be manifested the potential pre-pathological changes in the most sensitive to air pollution cardiopulmonary system, the same contingent underwent a treadmill exercise test. The results from it are presented in table № 3.

Table 3. Results of treadmill exercise test

\begin{tabular}{||c|c|c|c||}
\hline \hline Indices & Dimenssion & Boys & Girls \\
\hline $\mathrm{ATVO}_{2}$ & $\mathrm{~mL} / \mathrm{min}$ & $1352.6 \pm 342.6$ & $1124.9 \pm 181.1$ \\
\hline $\mathrm{VO}_{2}$ peak & $\mathrm{mL} / \mathrm{min}$ & $1682.3 \pm 404.0$ & $1423.8 \pm 237.1$ \\
\hline $\mathrm{VO}_{2} / \mathrm{kg}$ & $\mathrm{mL} / \mathrm{kg}$ & $31.8 \pm 5.14$ & $28.9 \pm 2.7$ \\
\hline $\mathrm{ATVCO}_{2}$ & $\mathrm{~mL} / \mathrm{min}$ & $1382.2 \pm 350.8$ & $1153.4 \pm 185.9$ \\
\hline $\mathrm{VCO}_{2}$ & $\mathrm{~mL} / \mathrm{min}$ & $1856.0 \pm 519.2$ & $1638.7 \pm 318.4$ \\
\hline $\mathrm{RER}$ & & $1.1 \pm 0.1$ & $1.1 \pm 0.1$ \\
\hline $\mathrm{ATVT}$ & $\mathrm{mL} / \mathrm{min}$ & $1144.8 \pm 273.2$ & $1014.7 \pm 199.3$ \\
\hline $\mathrm{VT}$ & $\mathrm{mL} / \mathrm{min}$ & $1328.5 \pm 357.1$ & $1199.5 \pm 237.4$ \\
\hline \hline
\end{tabular}

The results have shown differences between indices of boys and girls owing to their different anthropometric characteristics, but data about pre-pathological status are missing.

\section{CONCLUSION}

No pathologic changes were observed in the external breathing and physical capacity of the majority of the children studied, although in the more susceptible ones low degree air pollution caused reduction in some indices. The study of external breathing and physical capacity are adequate methods for health assessment of the influence of low degree pollution.

\section{REFERENCES}

1. Годишен доклад за състоянието на околната среда през 1994 год. (Зелена книга), МС на РБългария, София, 1995. 
2. Търновска Т., Н. Дянкова, Д. Кацарова, Н. Русева.Характеристика на атмосферното замърсяване при спад на промишленото производство във високо индустриализиран район. Хигиена и здравеопазване, XXXVIII, 1995, 24-27.

3. Търновска Т., Н. Иванов, А. Бабикян, Р. Дасари. Характеристика на атмосферното замърсяване в град Пловдив за периода 1990-1997 година. Сборник доклади от Юбилейната научна сесия 50 години СУБ Пловдив, т. II, 91-94.

4. Arena, R., J. Myers, M. A. Williams, M. Gulati et al. Assessment of Functional Capacity in Clinical and Research Settings. A Scientific Statement From the American Heart Association Committee on Exercise, Rehabilitation, and Prevention of the Council on Clinical Cardiology and the Council on Cardiovascular Nursing. Circulation, 2007, 116, 329-343.

5. Brunekreef, B., D. Dockery, M.

Kryzanowski. Epideiologic Studies on Short-term Effects of Low Levels of Major Ambient Air Pollution Components. Environmental Health Perspectives, 103, 1995, 2, 3-13.

6. Câra $\mathrm{AC}$, Buntinx F, Van den Akker M, Dinant GJ, Manolovici C. Industrial air pollution and children's respiratory health: A natural experiment in Calarasi, 13, 2007, 3, 135-143.

7. Chuturkova R., T. Turnovska, D. Iliev, Y. Iossifova. An assessment of the quality of the atmospheric air in two industrial regions in Bulgaria. Pro- ceedings of Sixth International Symposium \& Exhibition on Environmental Contamination in Central \& Eastern Europe and the Commonwealth of Independent States, 2003, Prague, Czech Republic, CD-ROM.

8. Cotes JE. Lung function. Assessment and Application in Medicine. Fifth Edition. Blackwell Sci. Publ., Oxford, 1993, 299-324.

9. Euling, S. Y., S. G. Selevan, O. H. Pescovitz, N. E. Skakkebaek. Role of Environmental Factors in the Timing of Puberty. Pediatrics, 2008, 121, S167-S171.

10. Jedrychowski, W., E. Flak, E. Mroz. The adverse effect of low levels of ambient air pollutants on lung function growth in preadolescent children. Environ Health Perspect. 107, 1999, 8, 669-674.

11. Katsouyanni,K.: Health effects of air pollution in Southern Europe: The interacting factors?; Environmental Health Perspectives, 103, 1995,2,23-27.

12. Robert O. Crapo. Pulmonary-Function Testing. The New England Journal of Medicine, 331, 1994, 1, 25-30.

13. Patton GC, Viner R. Pubertal transitions in health. Lancet. 2007; 396, 1130-1139.

14. Stajkova J., T. Turnovska. Air pollution characteristic of the town of Kardzali for the period of 1997-2001. Research Reports from the National Conference on the subject "Science, Environment and Stability Development", Union of Bulgarian Scientists, Veliko Tarnovo, 2002, 370-374. 